\title{
Green Accounting: Cost Measures
}

\author{
Krishna Moorthy, Peter Yacob \\ Faculty of Business Finance, University Tunku Abdul Rahman, Kampar, Perak, Malaysia \\ Email: krishnam@utar.edu.my, petery@utar.edu.my
}

Received October 31, 2012; revised December 3, 2012; accepted December 15, 2012

\begin{abstract}
In the past, environmental issues were often ignored by both, large companies and small medium enterprises. However, accounting for the environment or the acronym "Green accounting" is receiving increased attention in the recent times. Many companies, particularly small medium enterprises (SMEs) are now interested in being "green", as many investors place a high value on environmental responsibility. Many environmental costs can be significantly reduced or eliminated as a result of business decisions, ranging from operational and housekeeping changes, to investment in greener process technology to redesign processes or products. Industry and the green movement are tilting towards consensus on the pivotal concept of sustainable development. Better natural resource and green accounts would provide valuable insights into the interaction between the environment and the economy. However, implementing green accounting in organization such as SMEs in Malaysia, results in resistance or ignored due to some reasons such as lack of awareness, lack of ethical education, etc. This paper highlights the issues surrounding the firms green accounting in financial reporting. The key goal of this paper is to outline a set of green accounting measures that are to be addressed in environmental management accounting system of a firm.
\end{abstract}

Keywords: Green Accounting; Environmental Accounting; Green Costs; SMEs in Malaysia

\section{Introduction}

Green accounting is related to environmental information and environmental eco-auditing systems [1] and has been defined as 'the identification, tracking, analysis, and reporting of the materials and cost information associated with the environmental aspects of an organization [2]. Green accounting is relatively new and a developing field. However, in Malaysia the green accounting is considered at an infant stage because, the implementation of green accounting in organizations such as SMEs in Malaysia, results in resistance or ignored due to some reasons such as lack of awareness, lack of green and ethical education and so on. The green accounting deals with accounting and management issues relating to environmental and social impacts, regulations and restrictions, safety, environmentally sound, and economically viable energy production and supply [3]. The foremost role of green accounting is to tackle the social environmental problems and may have impact on attaining sustainable development and environment in any country and influences the company's behavior in confronting social and environmental responsibility issues.

The International Federation of Accountants discusses green accounting as "the management of environmental and economic performance through the development and implementation of appropriate environment related ac- counting systems and practices; while this may include reporting and auditing in some companies, green accounting typically may involve to the life cycle costing, full cost accounting, benefits assessment and strategic planning for environmental management”. Furthermore, the United Nations Division for Sustainable Development [4] emphasizes that green accounting systems generate information for internal decision making, where such information can be either physical or monetary in focus. Indeed, the United States Environment Protection Agency deems that "an important function of green accounting is to bring environmental costs to the attention of corporate stakeholders who may be able and motivated to identify ways of reducing or avoiding those costs while at the same time improving environmental quality”. In fact, the green accounting systems have the dual purposes of managing and improving the financial environmental performance of an entity. It can also consider how organizational operations impact environmental systems and issues [5].

In summary, it is known that businesses are formed to deliver services or produce products in order to earn a profit. In the 21st century, accounting goes beyond the bottom line of black or red and it includes "green", too. With the growing green consumer awareness, companies are more than ever expected to align its business strategies with environmental initiatives. Environmentally 
conscious companies have already discovered that they can generate business strategies to help them reduce their carbon footprint, minimize their environmental impact, make the best use of natural resources, become more energy efficient, reduce costs, and exhibit social responsibility all at the same time [6].

\section{Literature Review}

Amran and Devi [3] described that green accounting literature has paid little attention to either organizational influences on a company's practices or has a company's practices influenced its organization. Dinah Shelton [7] described the importance of and impact on the green auditing system in relation to the environmental development. She pointed out that the green auditing and accounting is the same and plays critical role in promoting the public and the environmental organizations that could be worked based on the human rights approach. It means that environmental education is working in line with the human rights documents context.

On the other hand, Schultz and Williamson [8] argued that the sustainability accounting, which is an ethic of accountability, standardization of sustainability and future prospects for corporate sustainability, accounting for sustainable development may lead to sustainability concept. Interestingly, Heba and Yousef [9] have discussed about the concept and understanding on the environmental accounting education. Their article explored the concepts of green accounting and the possibility of broadening the applicability of the environmental reporting concept to be utilized by governments to make businesses more responsible for their externalities. They discussed the importance of environmental accounting as part of the accounting management, overviews the past and the current regulatory and mandatory status of green accounting and its relationship on the different professsions.

Recognizing this, Mehenna and Vernon [10] described that the green accounting is an expansion path which deals and measures with the environmental performance and the integration of environmental policy with business policy. The business firm's strategy includes responding to capital and operating costs of pollution control equipment. This is caused by increasing public concerns over environmental issues, and by the recent government-led trend to incentive-based regulation. Furthermore, they found that the environmental component of the business strategy, producing the required performance reports and recognizing the multiple skills required to measure, compile and analyze the requisite data.

According to Jennifer Ouellette [11], chemical companies stand to benefit from a system of green accounting, leading to better determination of costs and management of resources. The traditional accounting methods used by chemical companies often do not provide adequate information on their environmental costs. This results in ill-informed and often costly management decisions. However, by incorporating environmental accounting procedures, industrial firms, regardless of size, can increase profits, use materials more efficiently, and protect the environment.

In fact, Lintott [12] argued that the green accounting evaluates a general measure of welfare that leads to costly management decisions. Problems of monetary valuation are likely to lead accounting procedures. Industrial firms, regardless of size, can increase profits, use correct estimation of environmental costs. Firms can also learn more about more robust view of sustainability, are ignored. The United Nations Handbook of National Accounting, stated about the growing pressures on the environment and increasing environmental awareness that have been generated the need to account for the manifold interactions between all sectors of the economy and the environment. The conventional national accounts focus on the measurement of economic performance and growth as reflected in market activity. It also deals with the sustainability of growth and development, the scope and coverage of economic accounting that needs to be broadened to include the use of non-marketed natural assets and losses in income generation resulting from the depletion and degradation of natural capital [13]. The conventional accounts do not apply the commonly used depreciation adjustment for human-made assets to natural assets. Since sustainable development includes economic and environmental dimensions, it is essential that national accounts reflect the use of natural assets in addition to produced capital consumption.

The above literature review gives the required input for the current topic. Ramanathan [14] looked at green accounting from the premise of social contract theory and based his argument. Green accounting requires multidisciplinary knowledge in behavioral science, engineering, sociology and even biology. The fundamental premise behind green accounting is that organizations should internalize environmental costs. Currently these costs are externalized, and the society bears the impact of an organization's adverse activities on the environment due to the fact it is a "public good". Internal environmental accounting mechanisms such as cost accounting attempts to trace costs of the organization's activities on the environment [15]. It is expected that once organizations are made accountable for these costs, they would be compelled to minimize the potentially harmful effects of such activities. Also, environmental accounting requires organizations to forecast the potential environmental impact of their activities and accordingly estimate their contingent liabilities and create provisions for environmental risks. 


\section{Green Accounting Measures}

The above literature review leads to the following green accounting measures in Table 1. The next step will consist of questioning the departments or functional services grouped according to processes, and within the processes, the specific environmental activities. A selection technique will be used, meant to reduce the excessive number of specific environmental activities, even a regrouping of these activities into processes. Based on questionnaires collected from the enterprise workers, the centralized information will be analyzed by the Green Accounting team. Based on this data, a preliminary dictionary of the most important environment-specific activities will be prepared. Also information will be collected about allocation units of environment-specific costs which the Activity Based Costing method can provide (environmental cost drivers).

\section{Conclusions}

The green accounting is an emerging aspect of accounting science that will influence, in the near future. The adoption of basic elements of green accounting will portray the role of environment in the economy as well as render easier the analysis of macroeconomic questions

Table 1. Green accounting measures.

\begin{tabular}{|c|c|}
\hline Description & Green Accounting Issues and Scope \\
\hline $\begin{array}{l}\text { Pollution } \\
\text { Prevention Costs }\end{array}$ & $\begin{array}{c}\text { Costs incurred to prevent air and water pollution } \\
\text { along with water treatment facilities and other } \\
\text { activities. }\end{array}$ \\
\hline $\begin{array}{l}\text { Environmental } \\
\text { Protection } \\
\text { Costs }\end{array}$ & $\begin{array}{c}\text { Costs of energy saving measures as well as costs of } \\
\text { global warming reduction measures. }\end{array}$ \\
\hline $\begin{array}{l}\text { Costs of } \\
\text { Resource } \\
\text { Recycling }\end{array}$ & $\begin{array}{l}\text { Costs incurred for waste reduction and disposal as } \\
\text { well as for water conservation, rainwater usage and } \\
\text { other measures aimed at efficient resources usage. }\end{array}$ \\
\hline $\begin{array}{l}\text { Environmental } \\
\text { Restoration Costs }\end{array}$ & $\begin{array}{l}\text { Cost of environmental restoration operations } \\
\text { (eliminating soil and ground water contamination, } \\
\text { environmental compensation, etc.) }\end{array}$ \\
\hline $\begin{array}{l}\text { Management } \\
\text { Costs }\end{array}$ & $\begin{array}{l}\text { Management-related environmental protection costs } \\
\text { including environmental promotion activities and } \\
\text { costs associated with acquiring and maintaining ISO } \\
14001 \text { certification. }\end{array}$ \\
\hline $\begin{array}{l}\text { Social Promotion } \\
\text { Activities Costs }\end{array}$ & $\begin{array}{c}\text { Environmental protection costs stemming from } \\
\text { participation in social activities such as participation } \\
\text { in organizations concerning with environmental } \\
\text { preservation etc. }\end{array}$ \\
\hline $\begin{array}{l}\text { Research and } \\
\text { Development } \\
\text { Costs }\end{array}$ & $\begin{array}{c}\text { Environmental protection costs for research and } \\
\text { Development activities and costs of environmental } \\
\text { solutions business activities (Green } \\
\text { product/environmental technology design and } \\
\text { development costs, environmental solutions business } \\
\text { costs, others) etc. }\end{array}$ \\
\hline
\end{tabular}

with the help of green accounting measures and thus, will lead the economy to a viable path.

Despite the fact that the corporate environmental expenses increase not only in importance but also in monetary units, some enterprises continue to underestimate and enter environmental costs in accounts as general expenses. However, some companies try to connect environmental costs with products or services but the methods of allocation cost used are inappropriate. When no proper allocation method is used, the manager of an enterprise does not receive reliable information with regard to the real costs and profits in order to maintain or change the products and/or processes.

Furthermore, the above situation prevents the effective follow-up of yield of an enterprise as well as the right pricing of products and the important activities for the maintenance of competitiveness of an enterprise. The green accounting still faces a number of problems, such as, the lack of support of information, specialized personnel as well as the absence of proportional international accounting models. In recent years, the efforts for the growth of environmental information systems have led to the creation of proportional systems of administration (Environmental Management Systems) which face problems with regard to the treatment of complicated environmental data. The new tendencies that are found in evolution foresee a more proactive environmental planning through the recognition and the reduction of environmental cost and consequently the improvement of profitability of enterprises.

\section{REFERENCES}

[1] C. Jasch, "Environmental Management Accounting Metrics, Procedures and Principles,” UN Division for Sustainable Development, Expert Working Group on Improving the Role of Government in the Promotion of Environmental Managerial Accounting, 2001.

[2] United Nations, "The Handbook of National Accounting, Studies in Methods Series F, No. 78 Integrated Environmental and Economic Accounting: An Operational Manual,” United Nations, New York, 2000.

[3] A. Amran and S. S. Devi, "The Impact of Government and Foreign Affiliate Influence on Corporate Social Reporting: The Case of Malaysia," Managerial Auditing Journal, Vol. 23, No 4, 2008, pp. 386-404. doi:10.1108/02686900810864327

[4] United Nations, "Division for Sustainable Development," United Nation, New York, 2001.

[5] KPMG, "Introducing the Triple Bottom Line,” 2010. http://www.kpmg.com/Global/en/IssuesAndIsights/Articles Publications/Press-releases/Pages/Kyoto Protocol http://unfccc.int/kyoto_protocol/items/2830.php

[6] K. H. Olsen, “The Clean Development Mechanism’s Contribution to Sustainable Development: A Review of the Literature," Climate Change, Vol. 84, No. 1, 2007, pp. 59- 


\section{3. doi:10.1007/s10584-007-9267-y}

[7] L. Shelton, "Techniques and Procedure in International Environmental Law. 'Environmental Audit," The United Nations Institute of Training and Research Palais des Nations, Geneva, 2004.

[8] K. Schultz and P. Williamson, "Gaining Competitive Advantage in a Carbon-Constrained World: Strategies for European Business,” European Management Journal, Vol. 23, No. 4, 2005, pp. 383-391.

[9] H. Y. M. Abdel-Rahim and Y. M. Abdel-Rahim. "Green Accounting-A Proposition for EA/ER Conceptual Implementation Methodology," Journal of Sustainability and Green Business, Vol. 5, No. 1, 2010, pp. 27-33.

[10] V. P. Dorweiler and M. Yakhou, "Environmental Accounting: An Essential Component of Business Strategy," Asian Institute of Technology Thailand Online, Vol. 13, No. 2, 2004, pp. 65-77.
[11] J. Ouellette, “Coagulants and Flocculants Rise," Chemical Marketing Reporter, Vol. 250, No. 15, 1996.

[12] J. Lintott, "The Environmental Accounting: Useful to Whom and for What?” Ecological Economics, Vol. 16, No. 3, 1999, pp. 179-190.

[13] F. O. Zadeh and A. Eskandari, "Firm Size as Company’s Characteristic and Level of Risk Disclosure: Review on Theories and Literatures," International Journal of Business and Social Science, Vol. 3, No. 17, 2012, pp. 9-17.

[14] K. V. Ramanathan, "Toward a Theory of Corporate Social Accounting," Accounting Review, Vol. 51, No. 3, 1976, pp. 516-528.

[15] L. M. Yee, S. Devi and E. W. S. Khin, "Kyoto Protocol and Social Accounting Implication on Global-Warming in Malaysia,” African Journal of Agricultural Research, Vol. 6, No. 6, 2011, pp. 1489-1499. 